\title{
Asdatown: The intersections of classed places and identities.
}

\section{Dr. B. Gidley and Dr. Alison Rooke}

\section{Dept of Sociology}

\section{Goldsmiths}

\section{Introduction}

This chapter will explore the intersections between classed places and identities, focusing on the UK and examining the ways in which the figures of the 'chav' and the 'pikey' have been represented in British popular culture and in official policy discourses. We will argue that these representations conflate the racialized identity of the Gypsy Traveller with white working class identities and draw on the presence or proximity of Irish or Gypsy Travellers to the white 'underclass' in order to metonymically racialize the white working class as a whole. The politics of space, we will argue, is central to this process. Existing sociological and cultural geography literature hints at the active role of the spatial imaginary in classing people (Charleworth 2000, Robson 2000, Haylett 2000, Hewitt 2005, Skeggs 2005). We will argue that particular spaces and places - housing estates, and places described as 'chav towns' - are used discursively as a way of fixing people in racialized class positions.

In British culture, there is a long history of reading poverty and class spatially. Indeed, the roots of British empirical sociology can be found in a middle class preoccupation with the poor working class others who could be located in districts of the city. While the persistence of poverty is explained in policy discourse in terms of 'cycles' and 'cultures' of poverty entrenched in a regressive or 'backwards' working 
class, we will argue that what is regressive - and tainted by its Victorian imperialist history - is the persistent classing gaze which fixes working class people in place.

\section{The role of place in poverty}

'Our cities were long ago sectioned into poorer and richer areas and... socially the distance between the poorest areas and the rest of the city was vast' (Mumford and Power 2004: 14).

At the turn of the nineteenth and twentieth century, the maps produced by Charles Booth represented cartographically the intensity of poverty in London, showing how poverty was geographically concentrated (Gidley 2000). A century later, the New Labour government published an Index of Multiple Deprivation (IMD), mapping the whole of the UK by intensity of a variety of forms of poverty (2001, revised in 2004). The IMD revealed the striking continuity of the geographical concentration of poverty across time (Davey Smith et al 2001, Economist 2001, Vaughan et al 2005). ${ }^{\mathrm{i}}$

There has subsequently been debate as to whether such deprived areas impart what the Social Exclusion Unit calls 'area effects' to their residents in which a 'culture' of 'worklessness' becomes the norm (Lupton 2003a). ${ }^{\text {ii }}$ As Hirsch writes, the correlation of place and poverty 'appears to have increased in recent years, with concentrations of disadvantage becoming more acute and people's long term prospect of escaping disadvantage more heavily influenced by geography' (Hirsch 2004: 16). The influence of geography on poverty has increased in part as some neighbourhoods are identified as ripe for 'regeneration' or 'gentrification' while others, such as outer city and post-industrial areas, continue to decline economically, their residents moving 
further into poverty (see Paton, this volume, Lupton 2003b). This phenomenon has been described in terms of 'postcode poverty', as disadvantage becomes geographically concentrated and acute and the possibilities of escaping poverty are increasingly circumscribed by poverty.

Certainly, research shows that, in poor areas, there is an interaction between 'deficits' in several different forms of 'capital', which drives the persistence of poverty in certain areas (Piachaud 2002). A concentration of poverty can be compounded, for example, by high rates of crime and other dangers, poor reputation and inadequate schooling. Research since the 1950s and 1960s, including the Plowden Report (Central Advisory Council for Education 1967), has shown that low educational attainment is a feature of poor neighbourhoods (Lupton 2004). This persists today: Lupton's (2004) work evidences the fact that school quality tends to be lower in high poverty areas than others. Similarly, many deprived areas are 'labour market deprived'; different forms of isolation, both social and geographic, of many deprived communities, may make it difficult for residents to get in touch with work opportunities and form the networks essential to creating such opportunities in the first instance (Smith 1999). In outer city areas, such as Newtown ${ }^{\mathrm{iii}}$, the area discussed in this chapter, this is largely about geographic isolation, often exacerbated by lack of transport. But in inner city areas, too, research shows that people can experience equally intense social isolation: many residents' geographies can be extremely circumscribed and constrained (Crabbe et al 2006, Räthzel 2008, Reay and Lucey 2000, Rooke et al 2005). Deprived areas may have a stigma attached to them in public opinion, and people from these areas may be discriminated against in their obtaining paid employment. So for example, Atkinson and Kintrea (cited by Lupton 2003a) 
found that the perceived 'reputation' of an area was important in structuring residents' perception of opportunities in the wider community.

\section{Difficult spaces: Newtown}

In this chapter we discuss the process by which certain kinds of places (specific estates) that contain certain kinds of people (the 'underclass') are characterized in terms of a pathological lack, relating one micro-level case study, that of Newtown, to macro level discourse. Newtown sits on the outskirts of London. A large part of the town is made up of an estate of social housing built in the inter-war years, 'Hopefields'. Newtown in general and Hopefields in particular appear in the 2001 census as having high indicators of 'deprivation' and 'social exclusion ${ }^{\text {iv, }}$. Hopefields was the location of the Newtown Neighbourhood Project, an action research project conducted by Real Strategies Ltd, West Kent Extra and the Centre for Urban and Community Research at Goldsmiths, University of London. The project set out to understand patterns of neighbourliness in this estate, which was widely described by agencies working there as 'hard to reach', 'difficult' and having problems with 'antisocial behaviour'. The project carried out interviews with these agencies, and then interviews with residents of the estate, both of which we will draw on in this chapter. The project also used more participatory methods in order to use research as a tool for making concrete improvements in the area (Gidley et al 2008). ${ }^{\mathrm{v}}$

This area in general (and in particular two streets on the Hopefields estate: Orange Grove and Flower Street) has suffered a negative reputation. In interviews with representatives of local agencies with a role of addressing social exclusion, this area and the two streets in particular were often differentiated from other streets in the 
location. Residents of these streets were perceived in a negative way by virtue of merely residing there. This appeared to have been the case for a long time. The agencies considered residents from these streets to make high levels of demands on services. Agencies discussed this population as lacking self-help skills, having health and social care problems associated with smoking and poor diet, having high levels of rent arrears and debt and benefit problems. As several interviewees iterated when approached with a proposal for an action research project: 'You will never get anything off the ground there'. This perception has been passed on to residents themselves, and experienced as shameful, with, for example, interviewees describing never naming the streets they came from when meeting new people. This chapter examines the process by which such 'area effects' work, how proper nouns - place names like Orange Grove and Flower Street - become metonyms for narratives of abjection, serving to fix classed subjects in place.

\section{The classing gaze: scopic regimes of class}

'[T]he conditions of emergence of a particular discursive class group

... were articulated, not through economic ordering, but rather through the use of moral and cultural categories' (Finch 1993: 11).

In the empirical research into the spatial concentration of poverty described above, the concepts which frame the analysis - deprivation, worklessness, deficit, poverty - are not neutral, but rather are already moral terms drawing their explanatory power from bourgeois moral regimes with deep cultural roots. We can see the deployment and development of such moral regimes at work in the ways in which class was envisaged 
- and thus made visible - by the early figures of British social science (Stedman Jones 1984, Gidley 2000). The classification used by statisticians today to frame class derive from the pioneering work of Charles Booth at the end of the nineteenth century, which grouped the different people of London into eight classes, from Class A at the bottom to $\mathrm{H}$ at the top. His schema was adopted for the 1911 Census and thus 'became the basis of all succeeding official analyses of social class' (Scott 1990: 8490).

Booth mapped the streets of London by these class categories, using a system of visual recognition to allocate them. The bottom two (A and B) of Booth's classes were the 'residuum', the surplus population, colour-coded with the darkest colours on his map.

'A. The lowest class, which consists of occasional labourers, street sellers, loafers, criminals, and semi-criminals... little regular family life... homeless outcasts... of low character... Their life is the life of savages... They degrade whatever they touch, and as individuals are perhaps incapable of improvement

B. Casual earnings, very poor [including many] who from shiftlessness, helplessness, idleness, or drink, are inevitably poor... [This is] the "leisure class" amongst the poor' (in Fried and Elman 1969: 11-14).

Comment: Can you check this last bit, I'm wondering if some meaning is lost in the '...' cut. I can figure out the general tone re 'the leisure class' but this is not entirely obvious.

Booth and other early urban explorers, such as Henry Mayhew and Friedrich Engels, entered the urban underworlds of the industrial metropolis with a desire to make sense of emerging urban industrialisation and the resultant conditions that the working 
classes were living in. These early sociological explorations were integral to the development of a Victorian bourgeois imaginary which produced the working class as almost less than human and in need of cultural reform and civilisation. As Stallybrass and White (1985), for example, have noted, the framing of class in these texts was informed by a particular set of moralizing tropes and figures (see Wilson-Kovacs, this volume). In the remainder of this section, we will briefly look at some such tropes, before demonstrating their remarkable persistence in both policy discourse and popular culture.

One such trope is the association of the working class with various forms of incivility, judged against a bourgeois standard. For example, Engels, one of the earliest urban explorers, writing in the 1840 s, condemned the Irish who made up a large percentage of the working class people he observed in Manchester for their drinking habits:

'Drink is the only thing which makes the Irishman's life worth having... his crudity, which places him but little above the savage, his contempt for all humane enjoyments, in which his very crudeness makes him incapable of sharing, his filth and poverty, all favour drunkenness. The temptation is great, he cannot resist it, and so when he has money he gets rid of it down his throat.' (1973: 118)

\begin{abstract}
A key form of incivility the social investigators associated with the working class was sexual excess. A central theme throughout Engels' work is the ways in the conditions of urbanisation under capitalism loosened the bonds of family and patriarchy leading to sexual immorality in the overcrowded conditions of the factory and the slum. Engels wrote of the 'filthy language' to which women are exposed on the factory
\end{abstract}


floor, where men are 'unsexed' and women are deprived of their 'womanliness' through physical labour. Financial independence under industrial capitalism led, for Engels, to a concern about the dangers of women falling into prostitution, as well as 'immorality, illegitimacy, the breakdown of family life, and bestial excess' (Wilson 1992: 73). The Victorian imaginary of the working classes and their unruly sexualities was deeply erotic: Walkowitz's (1994) and Weeks' (1989) work shows how the imaginaries of middle class reformers were realized in a concern with regulating working class women's sexualities through legislation and education.

In fact, it was not just the sexual behaviour of the working class that the middle class investigators found disgusting (but also desirable ${ }^{\mathrm{vi}}$ ): their very bodies were seen as excessively sexual, indeed excessive in general. The excessiveness of working class bodies in this discourse is understood by Stallybrass and White (1985) through Bakhtin's $(1968,1981)$ concepts: the working class body was figured as grotesque, infinitely permeable and spilling out, in contrast to the disciplined 'classical' body of bourgeois ideals.

Along with the corporeal excessiveness of the working class, middle class observers identified them with excessive forms of display and decoration. Mayhew's writing produces a taxonomy of the exotic dress and decorative practices of working class 'tribes' such as the costermongers with their baggy trousers, jewellery, tattoos. The late $19^{\text {th }}$ century figure of the 'gent' or 'swell', a working class man inappropriately dressed in high fashion clothing, as satirized in music hall songs and the comic character Ally Sloper continued to frame working class subcultures in terms of sartorial excess (Walkowitz 1994). 
The nineteenth century parents of social science such as Booth and Mayhew saw the working class as failing to respect the spatial order built into bourgeois morality. On the one hand, these investigators saw the working class as allowing the domestic to spill out of its proper place, the private sphere, into public, just as their bodily excess and ostentatious display of wealth was a spilling out of that which, according to bourgeois morality, ought to remain private. For example, the key indicators of belonging to the lower ranked classes in Booth's visual taxonomy were represented as various forms of spilling out: conducting domestic affairs on the street (for example by arguing loudly), hanging washing in the street and so on. In a departure from his normal scientific language, Booth wrote: 'No sooner do [the casual poor] make a street their own than it is ripe for destruction and should be destroyed' (1903: 186). At the same time, the investigators condemned the working class for allowing the undomesticated into the domestic sphere. Engels, for example, obsessively remarked on the Irish of Manchester keeping animals - in particular pigs, the ultimate signifiers of dirt - in their homes. In fact, for Engels, in the working class home, the domestic/wild distinction that guaranteed the human/animal distinction, was broken down - workers' homes, he wrote, were 'cattle-sheds for human beings' (1973: 82) rendering the proletariat infra-human. As the pigs became domestic, the proles became feral.

\section{The working class as race apart}

' $\ldots$ it is not surprising that the working class has gradually become a race apart from the English bourgeoisie.' (Engels 1973: 14) 
Crucially, each of these tropes - incivility, sexual immorality, bodily excess, excessive decoration and disordered space - were modalities through which the working class was racialized: constructed as a racial Other. Indeed, Engels constantly used the language of race to frame the proletariat, who he called 'these helots of modern society':

'in the working men's dwellings in Manchester, no cleanliness, no convenience and consequently no comfortable family life is possible; that in such dwellings only a physically degenerate race, robbed of all humanity, degraded, reduced morally and physically to bestiality, could feel comfortable and at home' (1973: 93).

The presence of the Irish amongst the working class reinforced this racialisation. Irish migrant labourers in the English urban landscape were exotic and abject racial others for the Victorian investigators, but also constituted a metonym for the working class, thereby racializing the whole class. Beatrice Potter, one of Booth's assistants, wrote in her diaries that: 'The worse scoundrel is the cockney-born Irishman. The woman is the Chinaman of the place, and drudges as the women of the savage races' (1982: 205). Most dockworkers were Irish and Potter clearly saw them as a race apart: 'lowlooking, bestial, content with their own condition' (ibid), and 'even the best of dockers bear the brand of London cunning and London restlessness' (ibid: 351). In Booth's writings, there is a constant association of Irish Catholics with all the vices of the lower classes: idleness, gambling, drinking, sexual immorality, coarse language: 'The poor Irish, who form the bulk of the Catholic population, are careless, but are naturally devout. They are rough-mannered and fight amongst themselves, or with the police at times, and they drink a great deal' (in Fried and Elman 1969: 160). 
We will now move on to argue that this racialisation, alongside the associated moralizing tropes, persists in contemporary middle class depictions of the proletariat. While racializing terms are muted in policy discourse, lingering in the survival of the language of Booth and his contemporaries, they are remarkably explicit in middle class popular culture and coalesce in the figures of the 'chav' and the 'pikey' and in a spatial imaginary which fixes working class people in place.

\section{Poor places, poor people}

The tropes discussed above - incivility, sexual immorality, bodily excess, excessive decoration and disordered space - have persisted over the years (Morris 1994), and are clearly in evidence in a range of contemporary discourses, doing considerable performative work in producing classed understandings of both subjectivities and spatialities. In this section, we discuss two spheres in which this occurs. Firstly, within UK New Labour discourse we see a continued concern about unruly and immoral working class bodies, a concern coalescing in certain figures and places which have come to serve as shorthand for incivility, immorality, excess and disorder. As Haylett writes, the policy field works as 'a symbolic regime partly constructed through representations of what "poor people and places" are and should be like according to modernising political imperative', based on putative 'observable differences in the ways of life of poor people' (2003: 57).

Crucially, though, these representations of poor people and places, and of the modernizing norm to which they are contrasted, are frequently drawn from the second sphere in which the racialized tropes discussed above circulate: in middle class 
popular cultural texts, and their spectacular and demeaning representations of working class bodies and places. In this section, we shall show each of these tropes, from incivility to spatial disorder, persisted today, circulating between and across the spheres of popular culture and policy discourse. We shall also show how some of these tropes were played out in the very local context of Hopefields and Newtown.

\section{Working class incivility}

The incivility that Engels and Booth described is today usually described as 'antisocial behaviour', a term that is heavily classed in its inflection and strongly associated in both policy and media discourse with the 'underclass' (Gillies 2005, Levitas 2005, Skeggs 2005, Garrett 2007, Sadler 2008). While politicians have unveiled ever-tougher measures to deal with incivility, from ASBOs and parenting orders to curfews and dispersal zones, middle class popular culture has given us texts like How to Get an ASBO (Wallace and Spanner 2006), part of a trend of cruel 'ironic' portrayals of Britain's social housing estates as places of crime,violence and stupidity which use humour in the service of classed contempt.

Hopefields in Newtown is consistently associated with anti-social behaviour in both local policy discourse and in local media representations. For example, an article about Newtown in local paper the News Shopper is entitled 'Welcome to Beirut': 'Burnt out cars, joyriding and violence on [Hopefields] in [Newtown] are turning it into an area where residents are "afraid to go about their everyday lives" (11.4.01). The area is portrayed in this and other articles as an unpleasant place to live where residents feared reprisals to their families if they complained and where complaining 
to the police was futile. Orange Grove and Flower Street in particular emerge as a 'problem area' for joyriding and 'chicken running'.

These media discourses directly affect the way the area is governed and policed, and the way that agencies providing services to the residents in the area perceive the residents. In interviews with local service providers, more than one interviewee described ASBOs (anti-social behaviour orders) as carried as medals by young people locally. Councillors asked the local police to use ASBOs and curfew orders to deal with joy riding ('Curfew for Estate' 15.11.00) and a dispersal zone was subsequently introduced in parts of Newtown (The Newtown Messenger, 9.6.05). A Community Warden was introduced in Newtown to address these issues - but was not allowed to walk the streets of Hopefields because it was considered too dangerous!

\section{Sexual and corporeal excess}

Victorian tropes of working class bodily excess continue in contemporary debates around promiscuity, obesity, smoking and health. Again, these tropes are evident in the media and popular culture. In television show such as You are What You Eat and Fat Kids Can't Hunt, the unruly working class body is repeatedly regulated and educated out of its unhealthy classed habitus by overwhelmingly thin middle class experts. The failure to regulate bodily tastes is firmly located with the lower classes, as with Jamie Oliver educating the working class dinner ladies, children and parents of Greenwich, London, in his Jamie's School Dinners programme. But, again, these concerns circulate from popular culture into policy discourse. Oliver went on to launch a 'Feed Me Better' campaign, shortly after which the education secretary, Ruth Kelly, announced investment in improving school meals. And in September 2005 the 
Department for Education and Skills established the Schools Food Trust. Concerns over childhood obesity, embodied in the figure of the fat child, coupled with a projection of poor parenting on to working class parents, thus circulate between popular culture (Jamie's School Dinners, Fat Kids Can't Hunt) and the policy field exemplified by the Schools Food Trust. The working class body, in these representations is guilty of what Nunn and Biressi (2008) describe as 'misdirected consumption' a popular trope in media representations of the working class as the 'undeserving, feckless and/or downright disorganised poor'. As well as this sort of irresponsible consumption, the 'undeserving' poor of Victorian bourgeois morality are frequently signified today by ostentatious display as a sign of excessive consumption. Drawing on Skeggs' work, Back writes:

"The phrase "dripping in gold" is used as a means to pour scorn on working-class women. It is meant to fix young women and the nouveau riche as brash or gaudy ... and mark them as inferior within the hierarchies of taste and class distinction. It is a stock phrase in the lexicon of class conceit.' (2007: 88-89).

Working class sexuality is another site whereby the grotesque body is as failing in self regulation. Popular culture is filled with images of unruly and promiscuous working class bodies (and especially female bodies) that spill over, from the Viz cartoon strip 'Fat Slags' to the Little Britain comedy character Vicky Pollard squeezed into a pink Kappa track suit (Tyler 2008), or in the obsessive focus on under-dressed over-weight young women behaving badly in reality TV programmes like Ibiza Uncovered and Undercover Britain. This is not merely a matter of classed prejudice in the realm of representation. Nunn and Biressi (2008), in a critical examination of the media's 
treatment of the case of Karen Mathews, the mother of nine year old Shannon whose 24 day disappearance was the subject of an extensive police investigation in April 2008, examine representations of Matthew's sexual excess: evidenced in her excessive breeding - her seeming inability to commit to respectable monogamy (having seven children to five fathers) - and her dependence on state benefits, which distilled a range of classed cultural meanings. The figures of the promiscuous working class woman, the single mother on benefits and the feckless father or boyfriend operate in a range of popular cultural milieus. These classed figures serve as shorthand for classed discourses which have real consequences in the social world, whether this is directly in policy agendas or implicity in post code discrimination.

Excessively decorated, promiscuous, voluptuous or obese bodies are ever present in popular culture and in particular the makeover TV genre. These grotesque bodies are contrasted to the somatic norm (Puwar 2004) of bourgeois femininity of middle class body. The latter is probably best represented by the disciplined bodies of female reality TV experts like What Not To Wear's Trinny Woodall and Susannah Constantine. As McRobbie points out, in an examination of the ways in which makeover TV generates and legitimates class antagonisms through an attention to gendered and classed embodiment,

' $[\mathrm{t}] \mathrm{he}$ bodies of young women are now to be understood according to a scale running from welfare-dependent, single maternity, marking failure, to well-groomed, slim, sophistication, marking success.' (2004: 102) 
The poles of this scale are represented, McRobbie notes, by the 'pram-faced girl' and the slim, stylish sophisticate - in other words, by Vicky Pollard and Trinny Woodall respectively.

In Newtown, in interviews with local agencies, interviewees described residents in exactly this language: images of cheap gold jewellery cropped up frequently in descriptions of local residents' ways and tastes. And, again, residents were aware of the ways that their tastes and bodies were perceived by others. To give just one example, a resident interviewee, a young woman, described her shame at being called fat:

'I don't like people calling me names, that's one ...well, I don't mind, it's when they say 'Fat', that gets me. That's the only word whatever gets me. When she calls me it I have to call it back to make myself feel $[\mathrm{OK}] \ldots$

The trope of bodily excess and immorality works discursively to incite judgement and generate classed positioning in today's cultural landscape. McNay and Skeggs, drawing on Bourdieu's work on the intimate connection between taste and bodily dispositions, interrogate the ways in which social value is 'read on the body', how it is 'produced through symbolic systems which set limits on who can be known and how' (Skeggs 2004: 26), at the centre of modern strategies of social control (McNay 1999). Crucially, Skeggs is concerned with how this process of inscription makes entitlements and fixes limits, 'enabling some groups to propertise their personhood and others to be beyond appropriation as the foundational ground of valuelessness from which others can mark and know their distinctions' (ibid). 
The scale from the fat slag to the A1 girl, like Booth's grid of Classes A to H, is a device through which subjects are gendered and classed. While make-over TV presents the illusion of the possibility of self-improvement, this scale is not one along which it is easy to move. The paradox of make-over TV is that it promises mobility while fixing subjects in place. These scales, moving from popular culture into policy, provide the repertoire of classed images through which the targets of initiatives like the Schools Food Trust are able to be imagined.

\section{Disordered space}

The spatial signifier 'the estate' has come to stand in for a range of classed understandings which cross the media landscape to be realized in the national imaginary. The Victorian pleasure of gazing on the spectacle of the chaos and sheer excess of working class, encapsulated in the early sociology of Booth and Engels, endures today in UK TV drama programmes such as Meet the Braithwaites and Shameless. Shameless takes place on a large council estate, Chatsworth, where notions of community, local identity, gender, ethnicity and sexuality collide in promiscuous ways. The estate is a complex moral universe that exists beneath the radar of official understandings of place or community. The programme is filled with sexual promiscuity, non-traditional families (i.e. not middle class, stably heterosexual, monogamous and nuclear), excessive drug and alcohol consumption and petty criminality, and narratives of complex community and ingenuity in the face of 'officialdom'.vii In Shameless, as Munt points out, 'the viewer is seduced into a cacophonic world that is not generally different from a Dickensian novel' (2008: 149). Shameless can be read as a 'popular cultural cartography' (Haylett 2000: 7) 
which represents estate life to the contemporary class tourist gazing from the comfort of their living room. In this way the programme serves as a reference point for understanding lives on estates in general. Newpaper columnist Allison Pearson, for example, writing in the Daily Mail, describes the Karen Mathews case discussed above, as possibly 'inspired by an episode of Channel 4's Shameless'.

'Whether or not this is the case, her life in general certainly echoes the TV series.

For those who've never seen it, Shameless is a brilliantly-scripted "comedy" set in underclass Britain. Feckless fathers, drug abuse, teenage pregnancies - name any contemporary social ill and Shameless shows it; not as a vision of a living hell, but as a two-fingers-up-to-authority scally-romp in which the moral of the story is that morals don't really matter...

Hilarious. Unless, of course, you happen to be a real child living in that kind of couldn't-care-less home. Anyone find the plight of Shannon Matthews funny? Thought not. Yet her family could come from Central Casting for Shameless Britain.'

Here, Pearson blurs the distinction between a fictional popular representation and a range of social policy concerns around 'underclass' behaviour. The imagery of estate life central to Shameless also appeared in Newtown in the agency interviews. The disordered space of the streets of Hopefields was regularly invoked - images of burntout cars and abandoned white goods on the front gardens, of the residents' habits of parking their cars on the kerb and of keeping horses and caravans in their back gardens - as spatial disorder comes to stand in for moral disorder. Thus, moral 
disorder, like bodily excess and incivility, continues to frame the working class as it did for the Victorians.

\section{The racialisation of the working class}

'the racialised production of the white working-class poor can be understood as part of the production of the modern social' (Haylett 2001: 354)

Earlier in this chapter, we argued that these tropes allowed Victorian social observers to construct the working class as a 'race apart'. In this section, we will argue that the persistence of these tropes means the continued racialisation of the working classes. Pearson's column cited in the previous section focuses in on two families in Shameless, the Gallaghers and McCanns. In the series, the Gallaghers in particular are coded as Irish, with common Irish names and Catholic signifiers in their homes (Munt 2008). As with the Irish in Engels' Manchester and Booth's East London, the Irishness of the Gallaghers, both racial others and metonyms for the English unruly classes, serves to racialize the class in general. ${ }^{\text {viii }}$

We can see a particularly extreme and widespread example of the intense racialisation of the working class today in the figure of the 'chav', through which white working class people are positioned as utterly racially other. In the mid-noughties, there was a wave of popular websites like Chav Scum and Chav Towns, followed by several wellselling books - such as The Little Book of Chavs: The Branded Guide to Britain's New Elite (Bok 2004), and Chav! A User's Guide to Britain's New Ruling Class (Wallace and Spanner 2004) - which constitute a veritable chav hate genre. The genre spells the return, in spectacular form, of the racializing and moralizing tropes we identified 
in the Victorian bourgeois. Here the tropes of incivility, sexual immorality, bodily excess, excessive display and disorderly space collide in a racialized popular imaginary. A glance at the proliferation of chav hate groups on the web provides manifold examples: there chav girls are breeding from an early age; their children have several fathers who are unable or unwilling to look after them. As Tyler (2008) demonstrates, the 'chav mum' embodies 'historically familiar' classed anxieties. The grotesque working class body, in the figure of the 'chav mum' (whether Karen Matthews or Vicky Pollard) works symbolically to vilify young white working class mothers through the emotion of disgust.

The intertwining of classed desire and disgust is also in evidence within contemporary gay male culture where the figure of the chav is an object of a desire and fascination. The pornographic video company Triga, with their video titles such as Fuck a hoodie, Skins and Scallies and proper Hardcore, reveals the extent to which the authenticity of working class masculinity is a marketable commodity (see Johnson 2008). Publicity for London's G-A-Y club's Chav night encourages its customers to come for night which celebrates 'The clothes, the attitude, the council estates' encouraging customers to 'Dress down as far as possible' for a night when 'It's time for the bad boys to take over G-A-Y or the middle class roughing it for one night only'. The spatial imaginary of class is clearly at work in the pornographic imagination where certain places (flats on Council estates, building sites) are the locus classicus for erotic cross-lass encounters. As the promotional material for one video Council Scum demonstrates: 'Soap dodgin, Special Brew and Freeview telly go hand in hand like an horse and cart especially when your a council flat bound piss poor dole robbin cunt! 
Filmed in Bermondsey South East London, these pillars of chav land UK are out for trouble!'

Crucially, chav hate is expressed in the space of humour. Most of the chav hate books are filed in bookshops and on the website Amazon under 'humour'; most of the chav hate groups on Facebook are in the 'Just for Fun' category. As Tyler (2008) notes, the space of humour enables the expression of violent hatred that would be unacceptable in other spheres. Facebook groups include 'Petition for the legalization of Chav Hunting!' (2,928 members), 'Whack-a-chav-a-day!' (2,389 members), 'SPIT ON A CHAV' (1,415 members), 'Kill the annoying chav playin loud music from his phone on public transport' (1,208 members), 'Save the UK... Kill a Chav' (1,098 members), 'I really dislike pikeys' (764 members), 'I fuckin' hate pikeys' (649 members), and 'Clean our Streets! Kill a Chav!!!' (just 172 members). ${ }^{\text {ix }}$ There is a continuity here with the space of humour within which reality TV works, including the dissemination of class conceit through programmes like What Not To Wear. Of these, McRobbie writes that 'denigration... is now done with a degree of self-conscious irony, both the presenters and the audiences are presumed to know that no harm is intended and that, in post politically-correct times, this is just good fun.' (McRobbie 2004:100).

The etymology of the word 'chav' is obscure and complex (Nayak 2003, Haywood and Yar 2006). One possible source is the Romany word 'chavvy', an affectionate term for a child (Bhopal and Myers 2008: 94). Closely related to the term 'chav' is 'pikey', which historically was associated with Gypsy Travellers and especially Irish Travellers. Although many people now use the term 'pikey' as a synonym for 'chav' (as in the Facebook chav hate groups mentioned above or on the chavscum website), 
it retains its derogatory racist valency. Thus the use of the term is an even more extreme example of the intense racialisation of the working class today.

The fact that the terms 'pikey' and 'chav' circulate from the space of humour, along with their blurry etymologies which allow their racial content to be easily denied, means that they can be expressed without the censure attached to other racist terms. As Bhopal and Myers write,

'the use of "paki" and "coon" is hugely restricted within British culture, but the use of "chav" as a near-equivalent post-millennium British marker for "white trash" has become quite commonplace... Similarly, the use of the word "pikey", with just a hint of irony, is considered acceptable despite the obviously derogatory nature of this term... It is not that they will not cause offence, but they will not offend in a way that would bring down any opprobrium upon [those who use them]' (ibid: 92-3).

This blurring and 'irony' mean that some mainstream users of the terms have received mild reprimand, while others get away with it - as would not be the case with terms like 'paki' and 'coon'.

\section{Spatialisation: chav towns}

Alongside the racialisation of the working class, we want to draw attention to the spatialisation of the classed imaginary. The spatial imaginary that led Booth to colour-code London's streets black to signify the 'lowest' classes endures today in the spatial politics of urban regeneration (the 'zones' of deprivation and exclusion at 
policy instruments are targeted), in moral discourses of 'sink estates', in indices of deprivation (Tonkiss 2000). As Lefebvre's work (1991) demonstrates, space is not a neutral backdrop that political and historical processes unfold upon; space is active in political and historical processes. Today, the politics of entitlement, inclusion and desirability are increasingly discussed and realized in spatial terms.

This has been a theme of Bev Skeggs work. As she points out, 'in contemporary Britain, geographical referencing is one of the contemporary shorthand ways of speaking class' (2004: 15). In political rhetoric, she writes, 'the word class is not mentioned, but alternative references such as "council estates", "projects", or even specific naming of areas occurs' (ibid: 112). Interviewing people in Manchester, Skeggs notes that "class was rarely articulated, although reference to taste and its lack was ubiquitous; rather, local areas were continually used as shorthand to name those whose presence was seen to be potentially threatening' (ibid). While working class people are kept in place through this geographical shorthand, the middle classes are able to move freely of this kind of placing, and fashion themselves through mobility, the ability to move from job to job in the pursuit of a career and better life chances: the middle class neo-liberal citizen is mobile; the fixity of the working classes signifies how they have been literally left behind by modernity.

In this power geometry, mobility - and control over mobility - reflect and reinforce power relationships of life chances. McKenzie's (2008) research into the experiences of working class women living in a stigmatized neighbourhood in the East Midlands shows that women were not only aware of the stigma that attaches to them when people are aware of where they are from, but that this awareness has material effects, 
in stopping them from taking up the very services, such as Sure Start, which are put in place to help them.

Relating what we have said about the racialisation of the contemporary working class to this emergent literature on spatialisation, we can see how the placing of class also serves to fix working class people as racial others. When people are located and positioned by reference to place names which are stigmatized in racially inflected ways, these people are themselves rendered racially other without explicit reference to 'race'.

We can see this process in evidence in the chav hate websites and books, which display an obsession with place and place names: endless lists of chav towns, interactive polls on which towns are 'chaviest'. The Chav Scum website has been defunct since 2006, but its offshoot Chav Towns (chavtowns.co.uk) survives - and flourishes, with new towns being added to its database more than daily. Similarly, alongside the many chav hate groups on Facebook, there are a number of groups which associate particular places with chavs (e.g. 'Chatham, The arse hole of Kent and home of the Chav...'). More interestingly, there are also several (e.g. 'Im from Maidstone but I aint no chav!', 'Sittingbourne is a chav hole but its still home')

which disavow the racializing stigma associated with chav locations while leaving the process of stigmatization and racialisation attached. In these Facebook groups, as in chavtowns.co.uk, we can see how cartographies of abjection are reproduced simultaneously at several different scales. While national discourses of the council estate and the disreputable bodies which populate it circulate, at a local level these discourses attach themselves to particular towns and even streets. 
The case of Newtown exemplifies the way that locations are classed through the racialized figure of the chav and the pikey. In 2005, a website called 'Knowhere Guide' posted that '[Newtown] is known as pikeyville ... there is nothing in [Newtown] except pikeys!' This was reported in the local newspaper, the Newtown Messenger (7.4.05), containing responses from the mayor, councillors and residents all praising Newtown and disavowing this negative labelling - but none commenting on the use of the racist word 'pikey'. A letter sent to the Messenger following the website story ('Not all areas are so nice to live in' 14.4.05) contests the positive account given by the mayor, drawing attention to problems in Orange Grove and Flower Street and the surrounding area, arguing there are problems with 'fly-tipping, joy riding, riding unlicensed motorcycles, the use of air rifles and catapults, causing damage to property and starting fires'. Later in the month, the Messenger reported that another website, this time www.chavtowns.co.uk, had targeted Newtwon, suggesting that 'In relative terms, [Newtown] is the Manchester United of chav towns. The shops are mostly out of business, but a few places that thrive, apart from Asda, are the kebab shop and Peacocks.' The article noted that the website mentioned other places in Kent, including Dartford and Bluewater, as 'chav towns' ('Chav Label Unfair to Area' 14.4.05). Once again local councillors were quoted defending the area against the comments, describing it as 'unfair'. Again, the terminology itself was not contested. A similar furore erupted in the Messenger the following year, after the BBC television presenter and media pundit Jeremy Clarkson commented on Travellers in the Times, associating them with nearby Dartford: 'I'm not sure what we're supposed to call them now. Travellers seem wrong as they all live in houses in Dartford in Kent.' These comments are interpreted in the Messenger as a 'Swipe at the 
town' (18.5.06). Thus the association of towns in Kent with settled Travellers is presented as negative. As with the articles on the website the previous year, the Clarkson story prompted letters overwhelmingly supporting his comments, using highly racialized language ('Town is full of tramps and pikeys' 25.5.06, 'Jeremy's right about travellers' 25.5.06).

The Clarkson comment - and the response to it - hint at a more complex history hidden behind the designation of Newtown as a chav town. Newtown, like the northeast corner of Kent in general, has a long history of association with Gypsy Travellers. The specifics of why so many Travellers live in Newtown are not known but it is possibly linked to the market gardening, fruit and hop picking and other forms of seasonal agricultural work locally (some Traveller residents referenced this activity during the course of the research). Today, Travellers are estimated to be the largest ethnic minority in Newtown. Local residents include first, second and third generations of housed Travellers. It is not uncommon for those of non-Traveller origin to have married into families of Traveller origins and vice versa. The majority of those of Traveller origins are from English Romany Gypsy decent, although the research team located Irish Travellers residing locally too. The following, concluding, section will show what is at stake in uncovering or holding on to these histories, as a way of producing working class pride rather than shame. 


\section{Once upon a Newtown: Alternative Narratives}

$[\mathrm{H}]$ ow to speak against poverty and indignity without speaking against who you are, what you are like and where you come from or having others do so on your behalf?" (Haylett 2003: 59).

For Back, 'working-class people articulate themselves through other means than bourgeois linguistic codes'; these means include tattoos and jewellery, which, as he argues in 'Inscriptions of Love' (2007: 71-96), can be extremely expressive if read by other working class people, while remaining mute when read through the moralistic bourgeois optic. This points to an alternative reading of the abjected bodies presented by What Not To Wear and Jamie's School Dinners. As Back argues, while the sovereign ring might be a metonym for disrespectability in the bourgeois taxonomy, it is also part of the lived affective fabric of working class cultural life, a way of linking life histories, marking rights of passage and moments of significance.

K [wife]: I mean 'Pikey' its quite trendy, what with jewellery, pikey things

S [husband]: But traditionally a Gypsy had an earring, and that's for the same reason that a merchant seaman had an earring for, which is, if he died, you take the earring, you sell it, you bury him with the money, that's the culture behind it. The same as the navy in the 18th century. You took the gold, you sold it and you buried him, he had a decent burial, you know.

The project of narrating this sort of alternative history, with all this emotional power, was taken up by the Newtown Neighbourhood Project, in a film entitled Once upon a 
Newtown. A group of young women from Hopefields estate, some of Gypsy Traveller origin, together researched the history of Newtown to produce an alternative, positive narrative which countered the negative stigmas associated with it. They chose to focus on the area's association with flowers as exemplifying the market gardening, hop picking and other agricultural practices which have flourished locally - and which are aspects of Newtown's history that tie it to Traveller history. These agricultural practices linger today in the pride local people take in gardening, a common feature of many working class areas, and the film's focus on this told a story about pride in this culture.

The short film that the young women in Newtown made stands as an alternative to the negative representations of the town which reduce Gypsy Traveller and working class lives to classed caricatures devoid of dignity, history or complexity. This project was a challenge, albeit in a small way, to the wider cultural and social processes of moralization, stigmatization and racialization described above, which all contribute to what Haylett calls 'the closing down of spaces of representation for the white working class, specifically spaces where cultural dignity and political significance can be forged' (2001: 354). The young women's film was part of a wider project of addressing the ways in which areas and populations associated with pathological lack, showing how terms like 'deprivation' and 'social exclusion' fail to do justice to complexity of their lives.

The Victorian tropes of working class incivility, bodily excess and disorderly space are, as we have shown here, clearly alive and well in the British bourgeois imaginary. Their persistence in the UK speaks to classed anxieties, and, as we have argued, serve 
to fix working class people in space symbolically and socially. These tropes constitute a form of symbolic violence; as they are put to work in the contemporary cultural landscape, they serve to racialise working class people, mark them as a 'race apart'. These representations in middle class popular culture, which are central to the production of the middle class self, intertwine desire and disgust. In their use, we can see the intersection of place and identity, as classed identities are pinned to stigmatised, classed locations. However, as the film project suggested, working class people have the ability to refuse this pinning down, and reclaim narratives that break out of these tropes. 


\section{Bibliography}

Anon. 1996. Walter: My Secret Life. London: Wordsworth Classic Erotica.

Back, L. 2007. The Art of Listening. London: Berg.

Bakhtin, M. 1968. Rabelais and his world. Cambridge: MIT Press.

Bakhtin, M. 1981. The dialogic imagination: four essays. Austin: University of Texas Press.

Bhopal, B., and Myers, M. 2008. Insiders, Outsiders and Others: Gypsies and Identity. Hatfield: University of Hertfordshire Press.

Bok, L. 2004. The Little Book of Chavs: The Branded Guide to Britain's New Elite. Bath: Crombie Jardine Publishing Limited.

Booth, C. 1903. Life and Labour of the People of London, volume 1, London: Macmillan.

Central Advisory Council for Education. 1967. Children and their Primary Schools ('The Plowden Report'), London: HMSO. 
Charleworth, S.J. 2000. A Phenomenology of Working Class Experience. Cambridge, Cambridge University Press.

Collins, M. 2004. The Likes of Us: A Biography of the White Working Class. London, Granta.

Crabbe, T. et al. 2006. 'Going the distance': Impact, journeys and distance travelled. Third interim National Positive Futures Case Study Research Report. London: Home Office.

Davey Smith, G. Dorling, D, and Shaw, M. 2001. Poverty, Inequality and Health in Britain 1800-2000: A Reader. Bristol, Policy Press.

The Economist 2001. Down-wind and out. Poverty has clung to some parts of London for at least a hundred years. Why? The Economist. 13 January 2001, p.35.

Engels, F. 1973. [1845] The Condition of the Working Class in England. London, Lawrence and Wishart.

Fried, A. and Elman. R.M. 1969. Charles Booth's London. London: Hutchinson.

Finch, L. 1993. The Classing Gaze: Sexuality, Class and Surveillance. New South Wales, Australia. Allen and Unwin. 
Garrett P.M. 2007. Making “Anti-Social Behaviour”: A Fragment on the Evolution of "ASBO Politics" in Britain. British Journal of Social Work, 37, 839-856.

Geoghegan, T. 2008. How offensive is the word "pikey"? BBC News 11 June 2008 http://news.bbc.co.uk/1/hi/magazine/7446274.stm

Gidley, B 2000. The Proletarian Other: Charles Booth and the Politics of Representation. London: Goldsmiths University of London.

Gidley, B. and Rooke, A. with Lelliott, S. and Humphry, D. 2008. Learning from the Local: The Newtown Neighbourhood Project. London: Goldsmiths University of London./West Kent Extra.

Gillies, V. 2005. Raising the "Meritocracy": Parenting and the Individualization of Social Class. Sociology, 39 (5), 835-853.

Haylett, C. 2001. Illegitimate Subjects? Abject Whites, Neoliberal Modernisation and middle Class Multiculturalism. Environment and Planning D: Society and Space, 19 (3), $351-370$.

Haylett, C. 2003. Culture, Class and Urban Policy: Reconsidering Inequality. Antipode, 29 (1), 1-31.

Hayward, K., and Yar, M. 2006. The "Chav" Phenomenon: Consumption, Media and the Construction of a New Underclass. Crime, Media, Culture 2 (1), 9-28. 
Hewitt, R. 2005. White Backlash and the Politics of Multiculturalism. Cambridge, Cambridge University Press.

Hirsch, D. 2004. Strategies against poverty: A shared road map. York: Joseph Rowntree Foundation.

Johnson, P. 2008. Rude Boys: The Homosexual Eroticization of Class. Sociology, 42 (1), 65-82.

Lawler, S. 2005. Disgusted subjects: the making of middle-class identities. The Sociological Review, 53 (3), 429-446.

Lefebvre, H. 1991. The Production of Space, Oxford: Basil Blackwell.

Levitas, R, 2005. The Inclusive Society, Social Exclusion and New Labour. Hampshire, Palgrave.

Lupton, R. 2003a.. 'Neighbourhood Effects': Can we measure them and does it Formatted: English (U.S.) matter? CASEpaper 73. Centre for the Analysis of Social Exclusion: London School of Economics.

Lupton, R. 2003b. Poverty Street: The dynamics of neighbourhood decline and renewal. CASEbrief 25. Centre for the Analysis of Social Exclusion: London School of Economics. 
Lupton, R 2004. Do Poor Neighbourhoods Mean Poor Schools? London: CASE Working Paper.

McKenzie, L. 2008., Social or Spatial Exclusion: How White Working Class Mothers of 'Mixed Race' Children 'Manage', Accept or Reject Inequality, Stigma and Stereotype: An outline of a Study Set in St Ann's in Nottingham. CRESC, Manchester: Putting Pierre Bourdieu to Work conference

McRobbie, A. 2004. Notes on "What not to wear" and post-feminist symbolic violence, in Feminism After Bourdieu edited by Adkins, L. and Skeggs, B. Oxford. Blackwell.

Morris, Lydia 1994. Dangerous Classes: The Underclass and Social Citizenship. London: Routledge

Mumford, Katherine and Power, Anne 2004. 'Abandonment as Opportunity' Manchester/Liverpool II Berlin: Shrinking Cities, 14-16.

Munt, S. 2008.. Queer Attachments: The Cultural Politics of Shame. Farnham, Ashgate.

Nayak, A. 2003 Race, Place and Globalization: Youth Cultures in a Changing World. Oxford, Berg. 
Nunn, H. and Biressi, A. 2008. Reflections on the "Undeserving Poor". Soundings Class and Culture Debate http://www.lwbooks.co.uk/journals/soundings/class_and_culture/nunnbiressi.html

Piachaud, D. 2002. Capital and the determinants of poverty and social exclusion. CASEpaper 60. Centre for the Analysis of Social Exclusion: London School of Economics.

Puwar, N.2004. Space Invaders: Race, Gender and Bodies Out of Place. Oxford, Berg.

Räthzel, N., Cohen, P., Back, L., Keith, M. and Hieronymus, A. 2008. Finding the way home: young people's stories of gender, ethnicity, class, and places in Hamburg and London, Göttingen: V\&R unipress

Reay, D. and Lucey, H. 2000. “I Don’t Really Like It Here But I Don’t Want To Be Anywhere Else": Children And Inner City Council Estates. Antipode, 32 (4), 410-428 Robson, G. 2000. 'No one likes us, we don't care': The Myth and Reality of Millwall Fandom. Oxford, Berg.

Rooke, A., Gidley, B., Shukra, K., Humphry, D. 2005. No Ball Games Here: The Hyde Sport Inquiry Report. London: Goldsmiths. 
Sadler, J. 2008. Implementing the Youth “Anti-social Behaviour” Agenda: Policing the Ashton Estate Youth Justice, 8 (1), 57-73.

Scott, J. 1990. A Matter of Record. Cambridge: Polity Press.

Skeggs, B. 1997. Formations of Class and Gender-Becoming Respectable. London, Sage.

Skeggs, B. 2004. Class, Self and Culture. London, Routledge.

Skeggs, B. 2005. Respectability: becoming a proper person. Inaugural lecture, Goldsmiths, University of London.

Simey, T.S. and M.B. 1960. Charles Booth: Social Scientist. Oxford, Oxford University Press.

Smith, G. 1999. Area-based initiatives: The rationale and options for area targeting.

CASEbrief 11. Centre for the Analysis of Social Exclusion: London School of Economics.

Stallybrass, P and White, A. 1986. The Politics and Poetics of Transgression. London, Methuen.

Stedman Jones, G. 1984. Outcast London. London: Penguin. 
Tonkiss, F. 2000. Social justice and the city: equity, cohesion and the politics of space, in A Companion to the City, edited by Bridge, G. and S. Watson, S. Oxford: Blackwell, 2000, 591-98.

Tyler, I. 2006. Chav Scum: The Filthy Politics of Social Class in Contemporary Britain. Feminist Media Studies, 9 (5)

Vaughan, L., et al. 2005. Space and Exclusion: Does Urban Morphology play a part in social deprivation? Area 37 (4), 402-412.

Walkowitz, J. 1994. The City of Dreadful Delight. London, Virago.

Wray, M. and Newitz, A. (eds). 1997. White Trash: Race and Class in America. London: Routledge.

Wallace, M. and Spanner, C. 2004. Chav! A User's Guide to Britain's New Ruling Class. London, Bantam Books.

Wallace, M. and Spanner, C. 2006. How to Get an ASBO. London, Virgin Books.

Ware, V. and Back, L. 2002. Out of Whiteness: Color, Politics and Culture. Chicago and London: University of Chicago Press.

Weeks, J. 1989. Sex, Politics and Society. The Regulation of Sexuality since 1800, London: Longman. 
Wilson, E. 1992. The Invisible Flaneur, New Left Review 191

\footnotetext{
${ }^{\mathrm{i}}$ This was first pointed out to us by Keib Thomas, a South London anti-poverty campaigner, who sadly passed away in 2007.

${ }^{1 i}$ We are grateful to India Court MacWeeney for additional research for this section.

iii All names and placenames in this chapter have been anonymised.

iv The term social exclusion, is as Levitas points out, intrinsically problematic, as it works to discursively place the poor and disadvantaged outside society. (Levitas 2005: 7)

${ }^{v}$ The majority of the research on the ground was carried out by Real Strategies: Sue Lelliott, Debbie Humphry, Ros Young and Imogen Slater. Additional research at Goldsmiths was carried out by Alison Rooke, Ben Gidley, Emma Jackson and Martin Myers. The project was managed by Eamonn Dillon and Genette Allen at West Kent Extra. We are grateful to all of our partners in this collaborative work, to the Housing Corporation who funded the project, and to the participants in Newtown. A full list of collaborators can be found in Gidley and Rooke (2008:50).

${ }^{v i}$ See for example Walter: My Secret Life, believed to be authored by the urban explorer Henry Spencer Ashbee, is an even more extreme example of this classed imaginary and its confusion of desire entwined with disgust

${ }^{\text {vii }}$ We do not have the space to go into this here, but we are not arguing that there is nothing more to Shameless than the ironic deployment of classed tropes. Especially when placed in the context of Paul Abbot's whole oeuvre, there are many aspects of the series which exceed such a description. Not the least of these, arguably, is the series' queerness.

${ }^{\text {viii }}$ We do not have the space here to address the important issue of the relationship between the figuring of the working class and the vexed question of whiteness - see Wray and Newitz (1997), Haylett (2001), Ware and Back (2002), Hewitt (2005), Bhopal and Myers (2008) and, from a very different perspective, Collins (2004).

${ }^{\text {ix }}$ Most of these groups also appear to be populated mainly by university students, resonating with Tyler's suggestion (2008) that chav hate is symptomatic of a more general anxiety about the mobility of the working classes, and an attempt to keep them out of middle class spaces such as the university.

${ }^{x}$ Examples include Jonathan Ross, reprimanded in 2004 for his use of the word 'pikey' on BBC Radio 4, which apparently did not hurt his career in any way comparable to his more recent non-racial gaffes; and Martin Brundle, Formula 1 commentator, whose use of the term in June 2008 led to an apology from ITV. While the Daily Mail was at the forefront of the campaign to censure the BBC over the October 2008 Jonathan/Russell Brand use of sexual language on BBC Radio 2, it defended Brundle, describing his censure as a form of humourless political correctness. One Mail columnist, Jasper Gerard, wrote: "As any rustic knows, "pikey" is rural-speak for "chav"... Alas "pikey" is sometimes linked to "gypsy", and gypsies are classed as a race; hence accusations of racism. But "pikey" describes folk who knock on doors offering "spare" Tarmac. It's a comment on the thin blue line, not blood lines. $\mathrm{Oh}$ and it was, dare one say, a joke' (http://www.telegraph.co.uk/sport/columnists/jaspergerard/2303018/Formula-One's-Martin-Brundleand-ITV-in-trouble,-but-what's-the-problem-with-'pikey'.html) Another, Des Kelly, wrote: 'To consider pikey a racial slur is as stupid as believing the word "hippy" has racist connotations, or that "hoodie" is offensive. Ban pikey, and then you might as well outlaw chav, townie, trailer trash, Hooray Henry, goth, Sloane, tinker and many more fairly innocuous labels' (quoted Geoghegan 2008). Crucially, the space of humour allows for a disavowal of the racism of such terms, its users are constructed as the victims of political correctness rather than the perpetrators of hate speech.
} 